IRA-International Journal of Management \& Social Sciences

ISSN 2455-2267; Vol.07, Issue 03 (2017)

Pg. no. 479-488

Institute of Research Advances

http://research-advances.org/index.php/RAJMSS

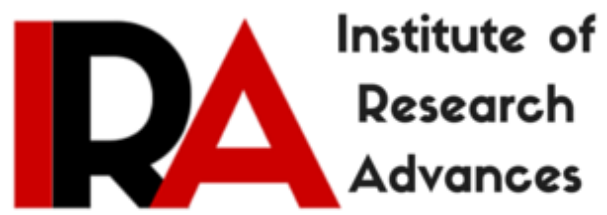

\title{
Effect of Human Capital and Leadership on Institutions' Performance and Competitive Advantages
}

\author{
Padli Hili ${ }^{1}$, Mursalim Umar Gani ${ }^{2}$, Nazir Hamzah ${ }^{3}$, Zainuddin Rahman ${ }^{4}$ \\ ${ }^{1}$ Faculty of Economics, University of Darussalam Ambon Doctoral Student in Faculty of \\ Economics, Muslim University of Indonesia, Indonesia. \\ ${ }^{2,3,4}$ Faculty of Economics, Muslim University of Indonesia, Indonesia.
}

Type of Review: Peer Reviewed.

DOI: http://dx.doi.org/10.21013/jmss.v7.n3.p9

\section{How to cite this paper:}

Hili, P., Gani, M., Hamzah, N., \& Rahman, Z. (2017). Effect of Human Capital and Leadership on Institutions' Performance and Competitive Advantages. IRA-International Journal of Management \& Social Sciences (ISSN 2455-2267), 7(3), 479-488. doi:http://dx.doi.org/10.21013/jmss.v7.n3.p9

(C) Institute of Research Advances

\section{(cc) EY-NO}

This work is licensed under a Creative Commons Attribution-Non Commercial 4.0 International License subject to proper citation to the publication source of the work.

Disclaimer: The scholarly papers as reviewed and published by the Institute of Research Advances (IRA) are the views and opinions of their respective authors and are not the views or opinions of the IRA. The IRA disclaims of any harm or loss caused due to the published content to any party. 


\begin{abstract}
This study analyzes the influence of human capital, leadership on performance and competitive advantage at 206 head of the study program university courses owned by private colleges in the Scope of Private High Education Coordinator has called KOPERTIS Region IX Sulawesi in Makassar. Sampling is done using the total population sampling technique. A result of testing the hypothesis with support of analysis moment of Structures Ver. 21 provides evidence that human capital, organizational learning and leadership and significant positive effect on the performance of the institution. Influences among other variables provide evidence that human capital, leadership and agency performance and significant positive impact on competitive advantage. On the other hand organizational learning and leadership are not significant positive effect on competitive advantage. The role of the institution's performance significantly effect in explaining the effect of human capital, organizational learning and leadership to competitive advantage.
\end{abstract}

Keywords: Human Capital, Leadership, Performance, Competitive advantage

\title{
Introduction
}

The ability of universities in Indonesia to grow and develop in a variety of competition is an advantage that should have higher education. The competitive advantage of current college are required both at national and global arena. The problem that always faces includes three things, namely equity, expansion and access to education, quality of education, relevance and competitiveness of education. The third problem has always been a debate in all circles about education in Indonesia. One of the main causes of these problems, due to the low competitiveness of the private lecturer private universities can compete with the lecturers in public universities. It takes effort to increase human resources, especially at private colleges and increasing the competitiveness of the lecturers so that universities, both public and private sector can compete on a competitive basis. College as a printer of professionals always tries to study this issue continuously, especially the competitiveness of lecturers to improve the quality of higher education (Baharuddin, 2015).

Competition is the core of the success or failure of an organization in which there are people who can compete to achieve a better rate (Porter, 1985). Private colleges' competitive advantage within the scope of Private High Education Coordinator has called KOPERTIS Region IX Sulawesi in Makassar, regarding how private colleges actually implement the strategy in activities that are practical. Universities are required to deliver a competent scholar; competence is a key condition that must be owned by scholars as college graduates, so that they are able to perform tasks profession properly and responsibly. Competence includes the service quality college student (customer focus) and or services of quality (business focus); with high achievement (people focus). Competence of college graduates is a combination of knowledge, skills, abilities and attitudes of college graduates earned during a student and are useful for college graduates to perform his duties in society (Porter, 1985).

The creation of a competitive advantage which is the organization's performance is influenced overview of the work of the organization in achieving its goals. The organization's performance is determined by the resources of the organization, in the form of physical resources such as human resources and intangible resources such as regulation, information, and policies. The concept of the performance of the organization explained that every public organization is required to provide services to the public and can be measured performance using the performance indicators to see if the organization is already carrying out their duties properly. Assessment of the performance of the organization is an activity comparing the actual results obtained with the planned (Ruky, 2001).

Human resources in this study is referred to as human capital, an organization will result in different performance if it is managed by different people, which means that human resources are different in 
managing assets in the same organization will produce added value are different, so it can be said that tangible assets owned by the organization is passive. The advantages of human resources to create the value added for the organization (Totanan, 2004). Human capital is a combination of knowledge, skills, innovation and the ability of individuals in performing their duties so as to create a value (Bontis, 2002).

The creation of competitive advantage is not only influenced by human capital and organizational performance but also needed leadership as the driving element of the organization's performance and competitive advantage. Leaders have an important role in college, many determinants of competitiveness of higher education, but the most decisive leadership capable and responsible, both at the university level and at the level of faculties and departments (Bachtiar, 2013). Leadership is defined as the ability to influence a group toward achievement of goals (Robbins, 2006).

Several previous studies have provided evidence that the investment in human capital has a significant impact on organizational performance (Winarno \& Troena, 2012; Hatch \& Dyer, 2004). Human capital and strategic leadership has significant effect on the competitive advantage (Memon et al., 2009). Leadership competencies have a significant impact on the competitive advantage (Mahdi \& Almsafir, 2014; Al-Zoubi, 2012). Reflecting productivity performance has a direct impact on competitive advantage (Sulistyawati \& Indrayani, 2012).

\section{Literature review Human Capital}

The terms of human capital is recognition that people in an organization and business are an essential important asset who Contribute to development and growth, in a similar way as physical assets such as machines and money. The collective attitude, skills and abilities of people Contribute to organization performance and productivity. Any expenditure in training, development, health and support is an investments not just an expense (Stockley, 2003).

Classical economic concept has a view of the humans as capital for the organization. Man is an Asset or a potential that can be harnessed to generate capital for the company. Human resources is the core of human existence exploited or used to realize the goals of the organization, means the application of human resource management is an essential part of human existence as capital to achieve organizational goals. Being the application of human capital in an organization in the form of exploiting all the potential possessed by humans is used by organizations as an asset that can realize the goal of the organization (Becker \& Woessmann, 2009).

The empirical evidence shows that human capital has a significant effect on organizational performance (Winarno \& Troena, 2012; Puji et al., 2012). Human capital has a significant impact on competitive advantage (Hatch \& Dyer, 2004; Memon et al., 2009). Competitive advantage at the college formed of competencies possessed by the university. Competency question is how the university is able to manage the assets and capabilities to create competitive advantage (Bradmore \& Smyrnios, 2009). There are several factors that can affect the level of competitive advantage at a university, the social structure, competences and marketing is done by the university. Thirdly it is a source of competitive advantage if managed properly will cause a positional advantage compared to its competitors (Arouet, 2009).

\section{Leadership}

Leadership is a person's ability to influence others in this regard subordinates such that the individual is willing to do the will of the leader though personally it might displease (Siagian, 2002). Leadership is the process of influencing others to understand and agree with what needs to be done and how the task was done effectively, as well as the process to facilitate the efforts of individuals and groups to achieve common goals (Yukl, 2001). 
Path Goal Theory explains that leaders encourage higher performance by providing activities that affect his subordinates to believe that valuable results can be achieved with a serious effort. A universally applicable leadership produces subordinate level of performance and satisfaction is high (House, 1971), empirical evidence shows that there is a significant positive impact on the ability of strategic leadership in sustainable competitive advantage (Mahdi \& Almsafir, 2014). Leadership style has a positive effect on business performance (Y1ld1z et al., 2014; Mutahar et al., 2015; Purwanto, 2015).

\section{Performance}

The achievement of an objective organization has only possible because of the actors' efforts that exist in the organization. Performance is the result of work achieved by a person or group within an organization for a certain period, in accordance with the authority and responsibility of each one, in achieving the objectives of the organization and is legal, does not violate the law and in accordance with moral and ethical (Prawirosentono, 1999).

Performance is the result achieved or something done in the form of products and services supplied individuals or groups, thus the performance can be seen from two sides, namely individuals and organizations (Dharma, 1986). Organizational performance is effectiveness which includes the achievement of organizational goals, efficiency taking into account the relationship between inputs and outputs as well as the adaptation that reflects the organization's ability to adapt to environmental changes (Homburg et al., 1999). Empirical facts prove that the performance has a direct impact on competitive advantage. Productivity gives most small direct influence on competitive advantage. (Sulistyawati \& Indrayani, 2012).

\section{Competitive Advantage}

Competitive advantage is the ability of an organization to achieve economic gains in profits which can be achieved by competitors in the market in the same industry. Companies that have a competitive advantage has always had the ability to understand the changes in market structure and being able to choose an effective marketing strategy (Porter, 1986). An organization that has achieved Competitive Advantage means has created economic value added is the difference between the perceived benefits and costs of the customer's product or service offered in comparison with its competitors (Peteraf \& Barney, 2003).

Environment in which the University operates is characterized by conditions and environmental conventions are changing; the change is more rapid than that occurred in previous periods; changes continuously (continuous); sensitivity to change. The ability to manage and develop the college has been felt necessary to use the principles of modern management and quality oriented to improve and enhance the educational activities as well as anticipation of the development of the larger institutions, in anticipation of increased globalization, and to prepare themselves to the gates of international competition. Thus the advantages have to get recognition of the quality process of a college to be important (Lewis \& Smith, 1994).

\section{Methods}

This study is explanatory research and that aims to analyze the influence of variables. The population in this study was 206 courses that are in private universities in the Scope of Kopertis Region IX Sulawesi in Makassar. The sampling methods are using the total population sampling technique. Analysis Moment of Structures Ver. 21 is used as a tool in conducting hypothesis testing. 


\section{Results}

Profile of Respondents

Table 1. Description of respondents

\begin{tabular}{|l|l|c|c|}
\hline \multicolumn{2}{|c|}{ Characteristics } & Frequency & Percent \\
\hline Gender & Male & 152 & 73.78 \\
& Female & 54 & 26,22 \\
\hline Ages & > 35 Years & 56 & 27,18 \\
& 36 - 45 Years & 72 & 34,96 \\
& 46 - 55 Years & 53 & 25,72 \\
& < 56 Years & 25 & 12,14 \\
\hline Lecturer Functional & Instructor & 80 & 38,83 \\
Positions & Assistant Professor & 71 & 34,46 \\
& Associate Professor & 52 & 25,24 \\
& Professor & 3 & 1,47 \\
\hline Experience in work & > 10 Years & 78 & 37,57 \\
& 21 - 20 Years & 82 & 39,81 \\
& $<31$ Years & 31 & 15,04 \\
& Level of Education & 15 & 7,28 \\
& Magister degree & 42 & 79,61 \\
& Ph.D. degree & & 20,39 \\
\hline
\end{tabular}

There are 206 head of study program is used as the unit of analysis, this is done with the consideration that the chairman of the study program has the function of leading the development of the study program.

Characteristics of respondents who indicate that served as chairman of the program of study at a private university in the city of Makassar mostly male sex that is 152 people or $73.78 \%$, characterized by the dominant respondents ages 36-45 years as many as 72 people or $34.96 \%$, further based on lecturer functional positions, respondents reflected by Instructor as many as 80 respondents or $38.83 \%$. For respondents working period dominated by between $11-20$ years as many as 82 people or $39.81 \%$, and the latter by level of education, respondents indicated the majority of respondents are Magister degree, as many as 164 people or $79.61 \%$.

Table 2. Goodness of fit test

\begin{tabular}{|l|c|c|c|}
\hline Criteria of Suitability Model & $\begin{array}{c}\text { Suitability of Index } \\
\text { Model }\end{array}$ & Cut-off Value & Description \\
\hline Chi-square $(\mathrm{df}=463)$ & 528.116 & 514.164 & Marginal \\
\hline probability & 0.019 & $\geq 0.05$ & Marginal \\
\hline RMSEA & 1.141 & $\leq 2.00$ & Good \\
\hline CMIN /DF & 0.026 & $\leq 0.08$ & Good \\
\hline GFI & 0.875 & $\geq 0.90$ & Marginal \\
\hline AGFI & 0.839 & $\geq 0.90$ & Marginal \\
\hline CFI & 0.979 & $\geq 0.95$ & Good \\
\hline$T L I$ & 0.974 & $\geq 0.95$ & Good \\
\hline
\end{tabular}

Based on the evaluation model can be shown that the eight criteria for goodness of fit indices were fulfilled only four, while chi-square, probability, GFI and AGFI not been met (marginal), but the chi- 
square value and probability deemed to have been good considering a sample is above 200 and the indicator above 25 so that these criteria cannot be in expectation (Hair, 2006), so that the overall model can be said to have been in accordance with the data and can be analyzed further.

\section{Effect of human capital on institution performance}

Humans have the potential that exists within him and is capital that can be used in business, work and in carrying out its activities, including the ability to manage an organization. Human capital is a significant potential of the individual to attempt or busy in performing their duties by exploiting and using the capital held in the form of knowledge, expertise, capacity, skill, creativity and innovation has.

The influence of human capital on the performance of the institution can be evidenced by the p-value of $0.000<0.05$, that the higher the human capital possessed course the higher the performance of the institution. Professor of human capital entrusted as chairman of the study program is the potential of its scientific knowledge and in carrying out their duties properly. Human capital are realized with positive reinforcement for the knowledge, expertise, capacity, skill, creativity and innovation are owned by the chairman of the study program provides significant positive contribution to the improved performance of the institution. The most important indicator in explaining the effect of human capital on the performance of the institution is obtained from the positive reinforcement on knowledge.

The results support the statement of some experts, those human resources is the core of human existence exploited or used to realize the goals of the organization; means the application of human resource management is an essential part of human existence as capital to achieve organizational goals (Becker \& Woessmann, 2009).

Human capital is a very important component in the innovation process. Man with all his ability when wielded a whole will produce exceptional performance. The theory explains that the importance of human capital with all its capabilities, potential and owned capital can produce exceptional performance thus can increase the performance of institutions. This means that the existing potential and ability in humans if used and used well will produce exceptional performance. Human energy potential and when deployed will produce exceptional performance both individually and within the organization (Edvinsson \& Malone, 1997). This study is supporting of the previous studies, that the human capital has a significant effect on organizational performance (Winarno \& Troena, 2012; Hatch \& Dyer, 2004).

\section{Effect of leadership on institution performance}

Leadership is a process of influencing others to understand and agree with what needs to be done and how the task was done effectively and process to facilitate the efforts of individuals and groups to achieve common goals. This means that a leader must be able to influence others and understand leadership well as the role of leader, designing the system, motivate, improve the working environment that is conducive and unify the interests to be done to control his subordinates in achieving common goals one of which is the performance of institutions better (Yukl, 2001).

Leadership influence on the performance of the institution can be evidenced by the p-value of 0.002 $<0.05$, the better the leadership of the chairman of the study program, the higher the performance of the institution. These results conclude that leadership and significant positive effect on the improvement of the performance of institutions. Leadership role equip universities with the knowledge base in order to improve the performance of the institution. Leadership is needed in the face of rapid environmental change. Leadership in this study were measured with a positive reinforcement of the role of leader, designing the system, motivate, improve the working environment and unite the different interests within the organization. The role of the leader is the most important indicator in explaining the leadership of the private university and be an asset for the study program, through effective leadership and adaptive 
conducted by the chairman of the study program to demonstrate an adequate role in carrying out activities and duties.

The results of this study are relevant to previous studies that many determinants of competitiveness of higher education, but the most decisive is the capable leadership and responsible both at the university level, as well as at the level of faculties and study programs. Thus the leader has a role to improve the competitiveness of the institution, skill in leading and responsible for what led. This means that the leader has a responsibility to achieve competitiveness and competitive advantage through the role of leader, designing the system, provide motivation, improve the working environment, brings together in a single vision, mission and objectives are cooperating in an effort to improve organizational performance better (Bachtiar, 2013). Leadership positive and significant impact on business performance (Y1ldiz et al., 2014; Mutahar et al., 2015)

\section{Effect of human capital on competitive advantage}

Human utilized for the benefit of human resource management. Essence as a human being utilized within the organization, the human is supported by the skills to do the engineering organization, humans are able to develop the potential of physical and mental health in carrying out organizational dynamics, human beings have social interaction to provide reinforcement existence of the organization and people have confidence value to realize and achieve organizational goals. This means that the existence of humans who have social interactions and other potential if used properly in the engineering of the organization will be able to achieve competitive advantage (Totanan, 2004).

The influence of human capital on competitive advantage can be demonstrated with a p-value of 0.033 $<0.05$, that the higher the level of human capital, the higher the level of competitive advantage owned by private universities. The high level of ability or potential knowledge of the head of the study program is proven to improve the behavior of the head of the study program so it can be a high-performance, the ability of the current knowledge is considered essential to be improved even more towards the better in order to achieve excellence clean. Under these conditions it can be concluded that human capital proved positive and significant impact on competitive advantage.

The results support previous research findings, that human capital have a significant effect on the competitive advantage (Hatch \& Dyer, 2004; Memon et al., 2009). Competitive advantage at the college formed of competencies possessed by the university. Competency question is how the university is able to manage the assets and capabilities to create competitive advantage (Bradmore \& Smyrnios, 2009).

\section{Effect of leadership on competitive advantage}

Leadership role in developing the vision and mission, develop influence through culture, implementing change, innovation and learning in order to achieve organizational goals effectively. One role of a leader is how the vision, mission and goals of the organization can be achieved through a variety of challenges that are environmental changes both internally and externally and adaptive to changes in the environment through a variety of innovations in accordance with the demands and changes. This means that leaders must be able to manage change in an effort to achieve competitive advantage (Toor \& Ogunlana, 2008).

Leadership effect on competitive advantage can be demonstrated with a p-value of $0.305>0.05$, that the higher the level of human capital but had no significant effect in improving the competitive advantage at a private university. This is because the ability of the chairman of the study program in designing the system has not been able to anticipate and adaptive to environmental changes are expected, so that no significant impact on the creation of private universities competitive advantage.

The findings of this study is different from empirical evidence, that many determinants of competitiveness of higher education, but the most decisive leadership capable and responsible, both at the 
university level and at the level of faculties and departments (Bachtiar, 2013). Leadership is defined as the ability to influence a group toward achievement of goals (Robbins, 2006). Strategic Leadership has significant effect on competitive advantage (Memon et al., 2009). Leadership competencies have a significant impact on the competitive advantage (Mahdi \& Almsafir, 2014; Al-Zoubi, 2012).

\section{Effect of institution performance on competitive advantage}

Institution performance is a responder on the work that achieved the chairman of the study program in an organization for a certain period, in accordance with the authority and responsibilities of each, within the framework of efforts to achieve the goals of the organization in question legally, does not violate law and in accordance with moral and ethical. The influence of the institution's performance on competitive advantage can be demonstrated with a p-value of $0.012<0.05$, that the higher the level of performance of the institution, the higher the ability of private universities in improving competitive advantage.

The instrumental of institutions performance can be improving competitive advantage. The performance of institutions is indispensable organization especially in the face of rapid environmental change. The performance of institutions is measured by the leadership, student affairs, human resources, curriculum, facilities, funding, governance, management systems, learning systems, academic atmosphere, information systems, internal quality assurance, graduates, research and community service contribute positive and significant impact on the creation of competitive advantage at the university within the region Kopertis IX Sulawesi in Makassar. This study supports the findings of previous researchers that as a reflection of the productivity performance have a direct impact on competitive advantage (Sulistyawati \& Indrayani, 2012).

\section{Effect of human capital as mediated institution performance on competitive advantage}

Knowledge in the context of human capital includes knowledge about the academic skills acquired through education. Skill is the ability to work or fulfill practical skills. Human capital is a very important component in the innovation process. Man with all his ability when deployed a whole will produce exceptional performance. Human capital in the form of the potential and capability of knowledge, expertise, capacity, skill, creativity and innovation if utilized properly will improve the performance of the organization to achieve competitive advantage (Edvinsson \& Malone, 1997).

The influence of human capital through institutional performance to competitive advantage can be demonstrated with a p-value of $0.029<0.05$, that the higher the human capital, the higher the level of competitive advantage through improved performance of the institution. This study is relevant to the statement that a person who has an advantage is those that have strong capital corresponding it has potential. Human excellence is always seen from how much knowledge of what is done, the results achieved and the benefits of the work produced. Human excellence is also seen from the skills of professionally able to carry out their work in a reliable, skilled and unskilled. Superior human being is capable of social interaction in various cooperation interests and goal attainment. Similarly, a superior man is man able to gain the trust by many people because it is believed to work well (Blaug, 1992).

\section{Effect of human capital as mediated institution performance on competitive advantage}

Leaders continue to encourage the creation of a higher performance by providing activities that affect his subordinates to believe that valuable results can be achieved with a serious effort (House, 1971). The leader is a person who has the talent to drive, steer or influence many people to follow orders and desire to achieve goals (Luthans et al., 2007). The influence of leadership through the institution's performance on competitive advantage can be demonstrated with a p-value of $0.049<0.05$, the better the leadership of the chairman of the study program, the higher the level of competitive advantage through improved performance of the institution. 
Indirect effects are built in the study were Influence Leadership Against Competitive Advantage Through Institutional performance based on results of the review have not found any empirical scholars desire to try to analyze the influence between these variables, so it is seen as the originality of this research.

\section{Conclusions and Recommendations}

Human Capital, demonstrated by the ability or the potential of the knowledge, potential skills, the capacity, the potential skills, abilities, creativity and ability to innovate and leadership embodied by the role of leader, system design, provide motivation, improve the working environment and brings together diverse interests, both these aspects provide a significant contribution in improving the performance of the institution.

Human Capital and Institutional Performance proven to improve the competitive advantage of the private universities, the opposite of good leadership has not been able to improve the performance of the institution. Human capital and leadership significantly influence competitive advantage through the performance of institutions. Recommended to university to improving the educational qualifications for the chairman of the study program run or perform activities, human capital is very supportive in bringing about institutional performance improvement through increased ability to work together professionally. Improving the leadership quality and human capital owned by the university in order to achieve sustainable competitive advantage. Serious efforts are needed to sustainably fix owned human capital in realizing competitive advantage through improved performance of the institution.

\section{References}

1. Al-Zoubi, M. R. (2012). Leadership competencies and competitive advantage empirical study on Jordan telecommunications. European Journal of Business and Management, 4(7), 234-247.

2. Arouet, F. M. (2009). Competitive advantage and the new higher education regime». Entelequia. Revista Interdisciplinar, 10, 21-35.

3. Bachtiar, N. (2013). University Competitiveness. Faculty of Economics - Andalas University. Padang.

4. Baharuddin, B. (2015). Influence of Supervision, Organizational Structure, Integration and Innovation on Excellence Competing University of Muhammadiyah Makassar. Journal of Scientific Educational Management, 6(1). 1050-1059

5. Becker, S. O., \& Woessmann, L. (2009). Was Weber wrong? A human capital theory of Protestant economic history. The Quarterly Journal of Economics, 124(2), 531-596.

6. Blaug, M. (1992). The empirical status of human capital theory: A slightly jaundiced survey. The economic value of education: Studies in the economics of education, edited by M. Blaug. Aldershot: Edward Elgar.

7. Bontis, N., \& Fitz-Enz, J. (2002). Intellectual capital ROI: a causal map of human capital antecedents and consequents. Journal of Intellectual capital, 3(3), 223-247.

8. Bradmore, D. J., \& Smyrnios, K. X. (2009). The writing on the wall: responses of Australian public universities to competition in global higher education. Higher Education Research \& Development, 28(5), 495-508.

9. Edvinsson, L., \& Malone, M. S. (1997). Intellectual Capital: Realizing Your Companyl's True Value by Finding Its Hidden Brainpower.

10. Furtwengler, Dale. (2007), Penilaian Kinerja, Penerbit Andi Ofset Yokyakarta.

11. Hair, J.F. Jr., Anderson, R.E., Tatham, R.L., \& Black, W.C. (2006). Multivariate Data Analysis (6th ed.). New Jersey: Prentice-Hall.

12. Hatch, N. W., \& Dyer, J. H. (2004). Human capital and learning as a source of sustainable competitive advantage. Strategic management journal, 25(12), 1155-1178.

13. Homburg, C., Krohmer, H., \& Workman Jr, J. P. (1999). Strategic consensus and performance: The role of strategy type and market-related dynamism. Strategic Management Journal, 339-357. 
14. House, R. J. (1971). A path goal theory of leader effectiveness. Administrative science quarterly, 321-339.

15. Lewis, R. G., \& Smith, D. H. (1994). Total Quality in Higher Education. Total Quality Series. St. Lucie Press, 100 E. Linton Blvd., Suite 403B, Delray Beach, FL 33483.

16. Luthans, F., Avolio, B. J., Avey, J. B., \& Norman, S. M. (2007). Positive psychological capital: Measurement and relationship with performance and satisfaction. Personnel psychology, 60(3), 541-572.

17. Mahdi, O. R., \& Almsafir, M. K. (2014). The role of strategic leadership in building sustainable competitive advantage in the academic environment. Procedia-Social and Behavioral Sciences, 129, 289-296.

18. Memon, M. A., Mangi, R. A., \& Rohra, C. L. (2009). Human capital a source of competitive advantage "Ideas for strategic leadership". Australian Journal of Basic and Applied Sciences, 3(4), 4182-4189.

19. Mutahar, A. Y., Rasli, A. M., \& Al-Ghazali, B. M. (2015). Relationship of Transformational Leadership, Organizational Learning and Organizational Performance. International Journal of Economics and Financial Issues, 5(1S).

20. Peteraf, M. A., \& Barney, J. B. (2003). Unraveling the resource- based tangle. Managerial and decision economics, 24(4), 309-323.

21. Porter, M. E. (1985). Competitive advantage: creating and sustaining superior performance. 1985. New York: FreePress.

22. Porter, M. E. (1986). Competition in global industries. Harvard Business Press.

23. Prawirosentono, Suryadi. (1999). Employee Performance Policy. BPFE. Yogyakarta.

24. Puji Astuti, Eny Endah \& Heru, R. (2012). Human capital, social capital and its impact on company performance (study on Sleman District Banking). In Proceeding Business Conference.Business and Global Issues 6-12 (pp. 5-1).

25. Purwanto, S. K. (2015). Effect of Leadership on Lecturer Performance in Higher Education. Journal of Management, 19(1), 47-58.

26. Robbins, Stephen. P. (2006). Organizational behavior. English Edition. PT. Index. GRAMEDIA GROUP. Jakarta.

27. Ruky, Achmad S, (2001). Payroll Management and Wages For. Company Employees, First Edition, Gramedia Pustaka Utama. Jakarta

28. Siagian, P.Sondang. (2002). Organizational Leadership \& Administrative Behavior ,. Jakarta: Gunung Agung Publisher.

29. Stockley, D (2003), E-learning definition and explanation. Retrieved December 12, 2007, from http://derekstockley.com.au/elearning-definition.html

30. Sulistyawati, A. I., \& Indrayani, R. A. (2012). The Effect of Employee Satisfaction, Training, Turnover, and Employee Productivity On The Competitive Advantage Through Company Performance. Journal of Accounting Dynamics, 4(2).

31. Toor, S. U. R., \& Ogunlana, S. O. (2008). Leadership skills and competencies for cross-cultural construction projects. International Journal of Human Resources Development and Management, $8(3), 192-215$.

32. Totanan, C. (2004). The Role of Intellectual Capital in Value Creation for Competitive Excellence, Journal of Entrepreneurs, No. 1, Tahun XXXIII, Januari: 27-31.

33. Winarno \& Troena, E. A. (2012). Effect of Human Capital and Learning of Organizationmediated Organizational Competence and Culture Innovation (Study at Private Higher Education in Kopertis V Yogyakarta). Journal of Application Management .10 (2). 239 - 251

34. Yıldız, S., Baştürk, F., \& Boz, İ. T. (2014). The effect of leadership and innovativeness on business performance. Procedia-Social and Behavioral Sciences, 150, 785-793.

35. Yukl, Gary. (2001). Leadership in Organization. New Jersey: Prentice-Hall, In. 